\title{
Peningkatan Kualitas Pola Desain dan Efisiensi Produksi UMKM Jilbab dan Baju Muslim di Kelurahan Rungkut Menanggal Surabaya
}

\author{
Diana Rapitasari \\ Universitas Bhayangkara Surabaya
}

\author{
Amirullah \\ Universitas Bhayangkara Surabaya
}

\begin{abstract}
Micro, Small and Medium Business, CV Kamilindo is engaged in the production and marketing business of hijab and Muslim clothing "Rira Clothing". It is located in Rungkut Menanggal, Surabaya. The problems in production aspects are (1) Motives of fashion design are still limited and its ability is only owned by the owner, and (2) Cutting of the material clothes with a certain thickness is still done with manual cloth scissors. The problems in production aspects have impact on: (1) The design patterns of hijab and Muslim clothes still follow the old patterns and are not able to keep up with the latest Muslim fashion, and (2) The process of cutting raw clothes material width and thickness into small sizes and ready to sew relatively long so that it inhibits production. The Community Partnership Program collaborates with the "Rira Clothing" as a partner to improve the quality of design patterns and production efficiencies in the Muslim hijab and clothing. From a number of problems above its program implements an advanced program including: (1) Increasing the knowledge, skills and quality of the design of headscarves and Muslim clothes using the design patterns of headscarves and Muslim clothes with the latest pattern to designers, and (2) Efficiency of time and energy of cutting raw materials width and thickness into small sizes and ready for sewing through appropriate technology innovation design of machine-cut raw material moved by electric motor. The results of the activities are: (1) The design patterns and products of Muslim headscarves and clothes with latest motifs created by partner designers, and (2) New Innovations in the appropriate technology machine for cutting raw materials with an electric motor.
\end{abstract}

Keywords: Convection; Hijab; Muslim dress; Pattern; Cloth cutting machine

\begin{abstract}
Abstrak
Usaha Kecil Menengah dan Mikro (UMKM) CV Kamilindo bergerak dalam bidang usaha produksi dan pemasaran konveksi jilbab dan baju muslim "Rira Clothing" serta berlokasi di Kelurahan Rungkut Menanggal Kota Surabaya. Permasalahan aspek produksi adalah (1) Motif rancangan busana (fashion) masih terbatas dan kemampuannya hanya dimiliki oleh pemilik mitra, dan (2) Pemotongan bahan kain Mitra dengan ketebalan tertentu masih dilakukan dengan gunting kain manual. Masalah pada aspek produksi berdampak pada: (1) Pola desain jilbab dan baju muslim masih mengikuti pola lama dan kurang bisa mengikuti perkembangan mode baju busana muslim terbaru, dan (2) Proses pemotongan bahan baku kain ukuran lebar dan tebal menjadi ukuran kecil dan siap jahit relatif lama sehingga menghambat produksi.Program Program Kemitraan Masyarakat (PKM) menggandeng UMKM "Rira Clothing" sebagai mitra dengan tujuan untuk meningkatkan kualitas pola desain dan efisiensi produksi pada UMKM jilbab dan baju muslim. Dari sejumlahpermasalahan diatas program PKM melaksanakan program lanjutan meliputi: (1) Peningkatan pengetahuan, keterampilan dan kualitas desain jilbab dan baju muslim menggunakan pola desain jilbab dan baju muslim dengan motif terbaru kepada desainer, dan (2) Efisiensi waktu dan tenaga pemotongan bahan baku kain ukuran lebar dan tebal menjadi ukuran kecil dan siap jahit melalui rancang bangun inovasi TTG mesin potong bahan baku kain listrik ke Mitra. Hasil kegiatan adalah: (1) Pola desain dan produk jilbab dan baju muslim dengan motif terbaru hasil kreasi desainer Mitra dan (2) Inovasi baru Teknologi Tepat Guna (TTG) mesin potong bahan baku kaindengan penggerak motor listrik.
\end{abstract}

Kata kunci: Konveksi; Jilbab; Baju muslim; Pola; Mesin potong kain 


\section{Pendahuluan}

Konveksi "Rira Clothing" berdiri tahun 2006 sebagai salah satu divisidari usaha jilbab Ananda dan Rizhani Moslem Wear dengan fokus usaha konveksi dan jasa penjahitan. Divisi produksi tersebut awalnya memproduksi produk merk sendiri. Selanjutnya pada awal 2011, UMKM mulai membuka peluang untuk produksi diluar merk sendiri, karena banyaknya permintaan dari luar untuk penjahitan baju muslim. Walaupun belum satu dekade berjalan, "Rira Clothing" sudah didukung oleh tim produksi yang kebanyakan adalah penjahit yangsudah berpengalaman selama puluhan tahun dalam bidang produksi konveksi dan garmen. Karena sejak awal sudah dikhususkan untuk menjahit produk busana muslim, tim produksi kami sudah terbiasa mengerjakan produk fashion, yang memang memiliki tingkat kesulitan lebih tinggi. Adanya tuntutan untuk selalu dinamis menyesuaikan dengan perkembangan trend fashion, tim produksi "Rira Clothing" diharuskan memiliki keahlian dan ketelatenan ekstra baik mengikuti perkembangan model, teknik pengerjaan dan aneka bahan yang digunakan. Gambar 1 menunjukkan UMKM konveksi jilbab dan baju muslim “Rira Clothing”.

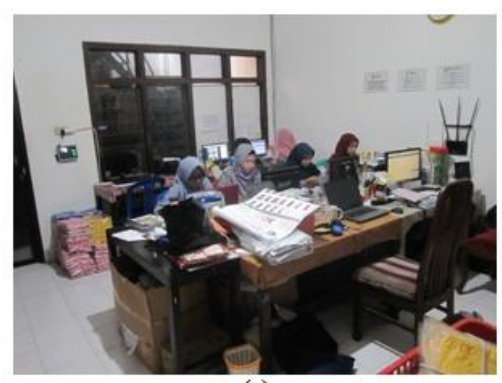

(a)

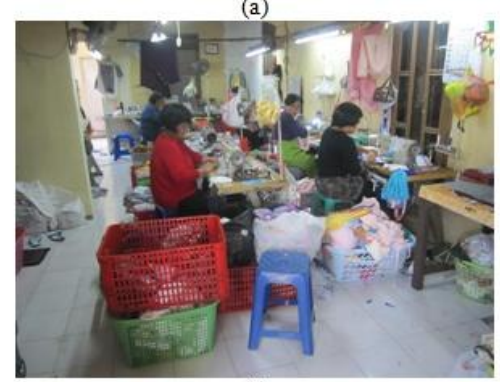

(c)

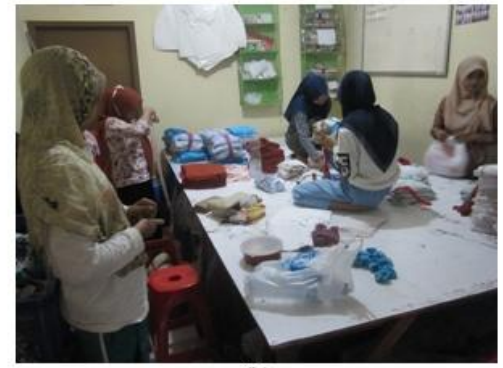

(b)

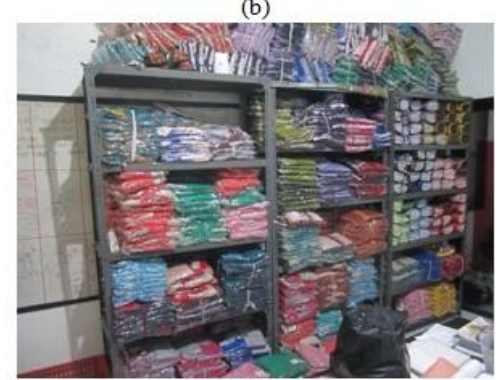

(d)

Gambar 1. UMKM Konveksi Jilbab dan Baju Muslim "Rira Clothing: (a) Ruang desainer dan marketing; (b) Ruang potong bahan baku kain; (c) Ruang jahit; (d) Ruang stok barang (Rapitasari, 2018)

Visi UMKM “Rira Clothing” adalah menjadi perusahaan garmen terbaik di Indonesia. Misi usaha adalah menghasilkan garmen dengan produk kualitas terbaik, memberikan manfaat sebaik-baiknya untuk stake holder, memberikan kesejahteraan yang memadai bagi karyawan, memberikan edukasi berkesinambungan untuk meningkatkan kualitas hidup karyawan. Budaya usaha adalah rasa memiliki; visi, misi, peralatan, maupun perusahaan adalah milik kita bersama; konsistensi: konsisten dalam perkataan dan diwujudkan dalam perbuatan; Berfikir: berfikir konsisten untuk perbaikan terus menerus; Bertindak: bekerja sebagai ibadah diwujudkan dalam kerjasama sinergis dan penuh integritas; Bersyukur: mensyukuri apapun hasil yang telah diraih (Ulfa, 2016). Manajemen Rira Clothing juga fokus pada pengembangan Sumber Daya Manusia (SDM) untuk tim Rira Clothing. Secara rutin, diadakan gathering dan edukasi yang bertujuan untuk meningkatkan kapasitas diri masing-masing anggota tim. Gambar 2 menujukkan website Rira Clothing. 


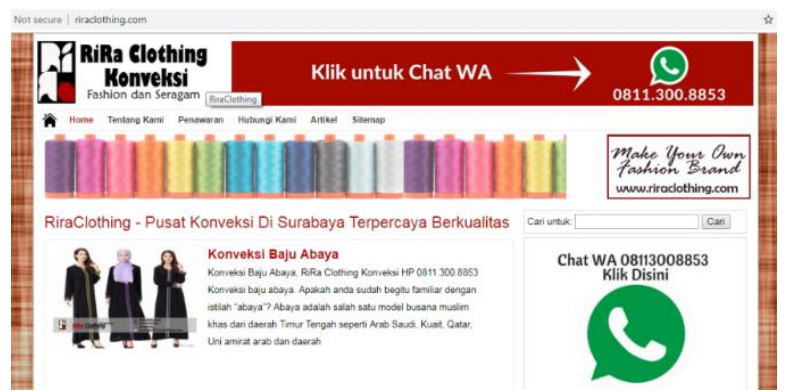

Gambar 2. Website Rira Clothing (Rapitasari, 2018)

Gunung Anyar adalah sebuah kecamatan di Kota Surabaya, Provinsi Jawa Timur. Kecamatan ini mempunyai empat kelurahan masing-masing Kelurahan Gunung Anyar, Gunung Anyar Tambak, Rungkut Menanggal, dan Rungkut Tengah. UMKM "Rira Clothing” menempati dua lokasi usaha, pertama kantor beralamat di Jalan Rungkut Barata VI/18 Kelurahan Rungkut Menanggal, Kecamatan Gunung Anyar, Kota Surabaya. Kantor ini berfungsi sebagai ruang administrasi, pemasaran (marketing), ruang pembuatan pola (desain) baju muslim, ruang potong kain, dan etalase penyimpanan baju muslim diam ambil/jual. Lokasi kedua adalah workshop beralamat di Jalan Rungkut Barata VI/24, berjarak sekitar 6 rumah dari lokasi kantor UMKM Rira Clothing. Workshop berfungsi sebagai tempat potong bahan kain dan menjahit produk jilbab dan baju muslim. Lokasi UMKM dapat dilihat pada Gambar 3.

UMKM Konveksi "Rira Clothing” beroperasi pada tahun 2006 dibawah naungan CV Kamilindo dibawah pimpinan seorang ibu rumah tangga Rizki Rahmadianti, S.T. Usaha ini pada awalnya merupakan produsen jilbab dan baju muslim merk "Ananda" dan "Rizhani" dengan sistem penjualan berdasarkan pesanan dari pelanggan. Untuk mengembangkan usaha, selanjutnya sejak tahun 2011 hingga sekarang UMKMtersebut juga memproduksi baju muslim anak balita perempuan yang diberi merk "Elbi" dengan kapasitas produk Elbi 5000 stel per bulan. Total pendapatan kotor (omzet) usaha setahun rata-rata sekitar Rp3 milyar. Dengan demikian mengacu pada kategori angka penjualan UMKM maka "Rira Clothing” termasuk dalam kategori usaha menengah (lebih dari Rp2,5 miliar).

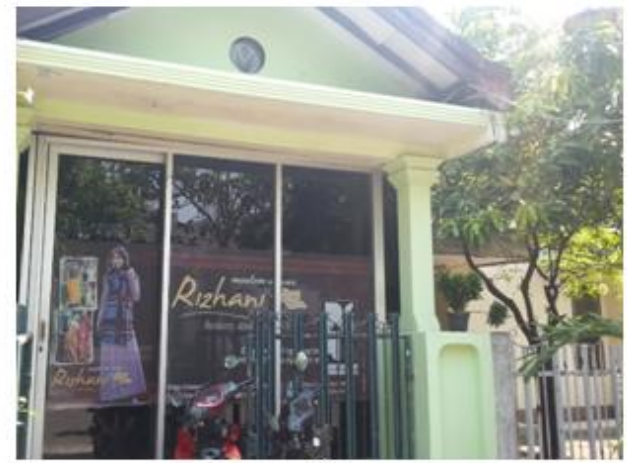

(a)

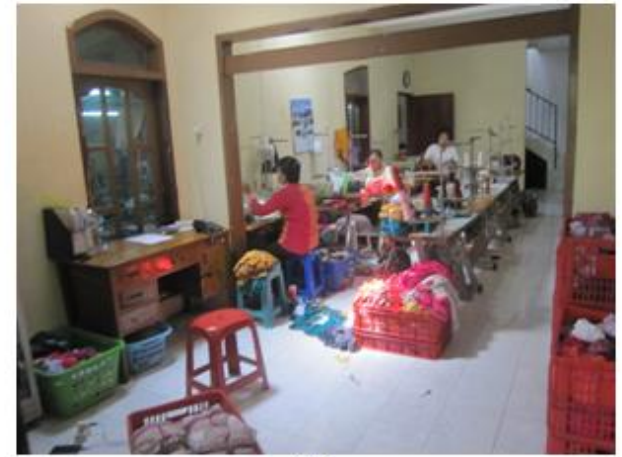

(b)

Gambar 3. Lokasi UMKM Konveksi “Rira Clothing”: (a) Kantor dan (b) Workshop

Jumlah tenaga kerja usaha konveksi "Rira Clothing" adalah 38 orang. Dari total tersebut 15 orang sebagai staf dan 23 orang sisanya sebagai penjahit tetap. Karyawan staf digaji dengan sistem bulanan dan bekerja pada bagian human resource department (HRD), supervisor (pengawas) produksi, marketing (sales) produk, akuntan, dan desainer mode. Karyawan penjahit tetap bekerja dan diupah berdasarkan jumlah baju yang mereka jahit (sistem borongan). Untuk momen tertentu misalnya menjelang lebaran ketika pesanan jilbab dan baju muslim semakin meningkat, maka UMKM akan menambah karyawan sebagai penjahit tidak tetap dengan upah 
sistem borongan. Karyawan dan penjahit rata-rata berasal dari warga sekitar Kelurahan Rungkut Menanggal sebagai komitmen pengelola UMKM untuk memberdayakan potensi, mengurangi pengangguran, dan memberikan manfaat bagi warga lokal dalam bidang jasa konveksi jilbab dan baju muslim (Rapitasari, 2018). Gambar 4 menunjukkan pimpinan CV Kamilindo sebagai pengelola UMKM Konveksi "Rira Clothing” dan anggota pengusul PKM ketika melakukan survei lapangan ke lokasi usaha di Kelurahan Rungkut Menanggal.

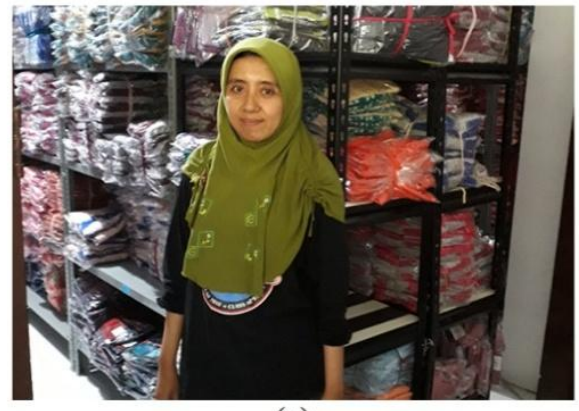

(a)

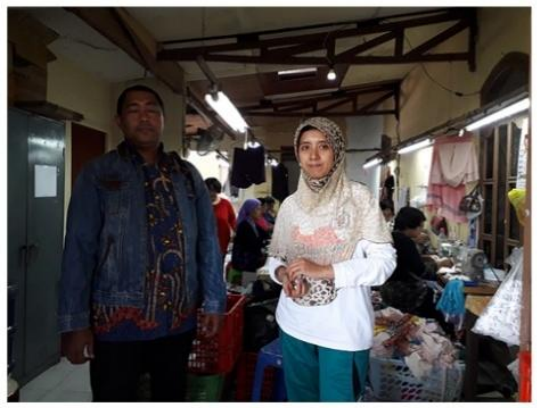

(b)

Gambar 4. (a) Pimpinan CV Kamilindo (Rizki Rahmadianti, S.T.) sebagai pemilik UMKM Konveksi "Rira Clothing" dan (b) anggota pengusul PKM ketika survei

Bagi para wanita muslim, pasti sudah tak asing dengan baju gamis atau jilbab. Jilbab adalah satu jenis pakaian muslim yang banyak dikenakan dan sudah banyak model-model jilbab yang dijual di pasaran.Tak hanya sebagai kebutuhan sandang, jilbab juga tanpa disadari telah menjadi penunjang penampilan. Jilbab saat ini telah tersedia dengan berbagai model dan jenis yang menyesuaikan dengan tren masa kini.Tak jarang jilbab juga digunakan oleh para artis Tanah Air, yang kemudian model jilbab khas para artis tersebut dijual dengan label 'jilbab artis'. Contohnya seperti Jilbab Syahrini atau Jilbab Ashanty.Jilbab memang dijual dengan harga beragam mulai dari puluhan ribu hingga ratusan ribu. Untuk membuat pola jilbab perlu disiapkan alat-alat seperti pita meteran, kertas pola (bisa gunakan kertas apapun), pensil, penghapus gunting, dan penggaris. Cara membuat pola baju jilbab yang pertama adalah mengukur jilbab. Siapkan pita meteran, pensil, dan kertas untuk mencatat ukuran-ukuran yang ada. Tabel 1 menunjukkan bagian yang perlu diukur sebelum membuat pola jilbab (Sendari, 2019).

Tabel 1. Bagian Tubuh yang Diukur Sebelum Membuat Pola Jilbab

\begin{tabular}{|c|c|c|}
\hline No. & Parameter & Cara Mengukur \\
\hline 1 & Panjang Jilbab & $\begin{array}{l}\text { Ukur panjang jilbab dimulai dari ujung pundak atas sampai } \\
\text { mata kaki }\end{array}$ \\
\hline 2 & Lingkar Dada & $\begin{array}{l}\text { Ukur melingkar dari bawah ketiak hingga bagian dada yang } \\
\text { menonjol }\end{array}$ \\
\hline 3 & Lingkar Leher & Lingkarkan pita meteran dari hingga bagian leher yang terbesar. \\
\hline 4 & Panjang Lengan & $\begin{array}{l}\text { Panjang lengan diukur dari pundak bawah sampai pergelangan } \\
\text { tangan. }\end{array}$ \\
\hline 5 & Lebar Bahu & $\begin{array}{l}\text { Lebar bahu diukur mulai titik bahu pada leher tertinggi sampai } \\
\text { titik bahu yang paling rendah pada ujung bahu bagian lengan. }\end{array}$ \\
\hline 6 & Lebar Pinggul & $\begin{array}{l}\text { Ukur melingkar bagian pinggul, lingkar pinggul kurang lebih } \\
\text { berada } 20 \mathrm{~cm} \text { dari lingkar pinggang }\end{array}$ \\
\hline 7 & Lebar & Ukur melingkar bagian pinggang atau bagian yang terkecil. \\
\hline 8 & $\begin{array}{l}\text { Lebar Pergelangan } \\
\text { Tangan }\end{array}$ & Ukur melingkar pergelangan tangan \\
\hline 9 & $\begin{array}{l}\text { Lingkar Kerung } \\
\text { Lengan }\end{array}$ & $\begin{array}{l}\text { Lingkarkan pita meteran pada sekeliling kerung lengan dari titik } \\
\text { bahu melalui ketiak sampai kembali ke titik bahu awal. }\end{array}$ \\
\hline
\end{tabular}


Ada empat pola pada pembuatan baju jilbab antara-lain: pola depan, pola belakang, pola lengan, dan pola kerah. Pola ini berbeda satu sama lain sesuai dengan fungsinya dan sesuai ukuran bagian tubuh yang telah diperoleh sebelumnya. Tabel 2 menunjukkan jenis dan cara membuat pola baju jilbab (Sendari, 2019).

Tabel 2. Posisi dan Cara Membuat Pola Baju Jilbab

\begin{tabular}{cl}
\hline No. & Posisi Pola \\
\hline 1 & Pola Depan \\
\end{tabular}

Cara Pembuatan

(a) Buat pola depan berupa garis lurus dengan panjang yang sesuai dengan panjang baju yang telah diukur sebelumnya. (b) Gambar lingkar leher dengan setengah ukuran lingkar leher. Kemudian gambarkan lebar bahu sesuai ukuran. (c) Setelah itu gambar lingkar kerung lengan setengah dari ukuran kerung lengan Anda dan tambahkan $2 \mathrm{~cm}$ untuk ruang jahitan. (d) Menuju ke bawah, untuk lebar baju, ukur seperempat lingkar pinggang seperti pada gambar.

(e) Kemudian untuk lingkar pinggul digambarkan $20 \mathrm{~cm}$ di bawah lingkar pinggang dengan ukuran seperempat lingkar pinggul ditambah $1 \mathrm{~cm}$. (f) Untuk lebar bagian bawah jilbab, ukur dengan cara menggambar seperempat ukuran lingkar pinggul ditambah 4 $\mathrm{cm}$. (g) Tarik garis antara bagian bawah kerung lengan, lingkar pinggang, lingkar pinggul dan bagian bawah jilbab hingga membentuk seperempat pola. (h) Gunakan pola ini untuk memotong kain pada bagian depan jilbab.

2 Pola Belakang

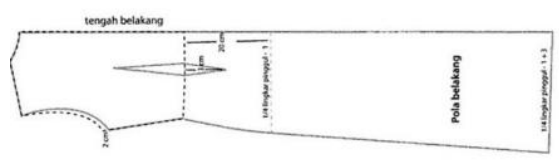

(a) Sama seperti pola depan, buat garis lurus sesuai dengan panjang baju yang telah diukur. (b) Untuk lingkar leher, gambar lingkar leher namun dengan ukuran setengah lingkar leher ditambah $3 \mathrm{~cm}$. (c) Setelah itu gambar lebar bahu dan kerung lengan. (d) Untuk kerung lengan dibuat dengan ukuran setengah kerung lengan ditambah $2 \mathrm{~cm}$. (e) Untuk lebar pinggang sama seperti pola depan dengan mengunakan ukuran seperempat lingkar pinggang.

(f) Untuk bagian pinggul juga digambarkan 20 $\mathrm{cm}$ di bawah lingkar pinggang dan ukurannya dibuat seperempat lingkar pinggul dikurangi 1 $\mathrm{cm}$. (g) Untuk bagian paling bawah jilbab, ukur dengan seperempat lingkar pinggul dengan dikurangi $1 \mathrm{~cm}$ ditambah $3 \mathrm{~cm}$. 


\begin{tabular}{|c|c|c|}
\hline No. & Posisi Pola & Cara Pembuatan \\
\hline 3 & Pola Lengan & $\begin{array}{l}\text { (a) Ukur pola lengan dengan panjang sesuai } \\
\text { dengan panjang lengan yang telah diukur } \\
\text { sebelumnya. (b) Untuk bagian atas gambar } \\
\text { lengkungan seperti pada gambar di atas dengan } \\
\text { ukuran sesuai lingkar kerung lengan yang telah } \\
\text { diukur sebelumnya. (c) Untuk ukuran lengan } \\
\text { bagian bawah atau pergelangan tangan, } \\
\text { sesuaikan dengan ukuran pergelangan tangan } \\
\text { Anda. }\end{array}$ \\
\hline
\end{tabular}

4 Pola Kerah

Pola Kerah Gamis

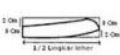

(a) Buat pola dengan ukuran lebar sesuai dengan setengah lingkar leher dan panjang 10 cm. (b) Gambar kerah pada pola tersebut sesuai dengan keinginan Anda.

\begin{abstract}
Comber kemboli polt pada kertos
Usaha UMKM "Rira Clothing" bergerak dalam bidang jilbab dan baju muslim. Segmen pasar usahanya yaitu jasa dengan menerima pesanan menjahit jilbab/baju dewasa dari pihak luar(merk milik pemesan) dan produksi jilbab untuk balita perempuan (merk sendiri "Elbi"). Pertimbangan hanya membuat produk jilbab balita perempuan karena: (1) modal relatif terbatas, (2) pasarnya relatif fokus pada segmen tertentu, dan (3) belum dimasuki oleh UMKM lain sehingga kompetitornya relatif sedikit baik di Surabaya maupun Jawa-Timur. Gambar 5 menunjukkan contoh produk baju balita perempuan Merk "Elbi" ( Panggabean, 2013.).
\end{abstract}
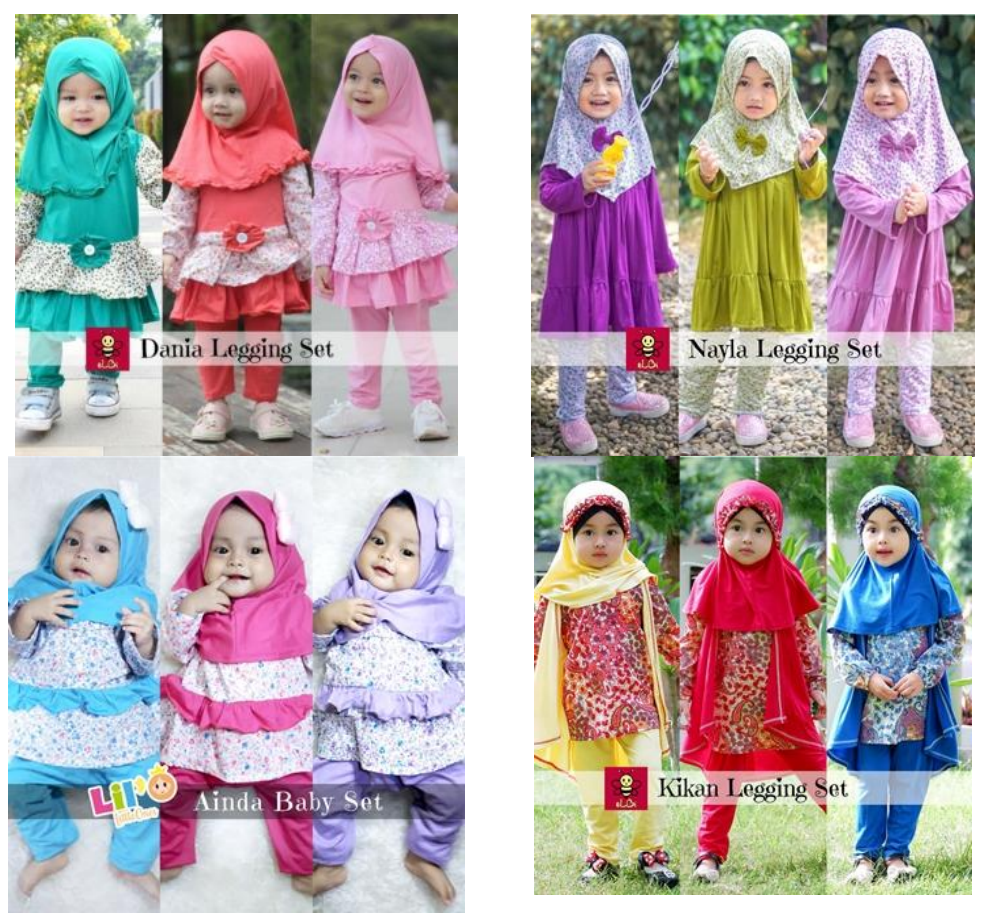

Gambar 5. Contoh Produk Baju Balita Anak Merk "Elbi" 


\section{Prioritas Permasalahan Mitra}

Berdasarkan pada analisis situasi, maka permasalahan mitra PKM yaitu UMKM Konveksi Jilbab dan Baju Muslim "Rira Cloting” mencakup aspek produksi, manajemen dan pemasaran. Permasalahan dari sisi produksi salah satunya adalah motif dan pola rancangan busana (fashion) masih terbatas. Permasalahan muncul karena sejak usaha berdiri, desainer UMKM Konveksi "Rira Clothing” hanya dilakukan sendiri oleh pemilik mitra (Rizki Rahmadianti, S.T.). Dampaknya adalah pola desain jilbab dan baju muslim mitra PKM masih mengikuti pola lama dan kurang bisa mengikuti perkembangan mode baju busana muslim terbaru. Kendala ini disiasati oleh pemilik mitra dengan belajar mode atau desain baju muslim terbaru. Kendalanya adalah latar belakang pendidikan perancang bukan dalam bidang tata-busana melainkan S1 Teknik Elektro, sehingga hasil desainnya relatif terbatas dan tidak terlalu maksimal khususnya untuk pola yang membutuhkan ketrampilan/akurasi desain tinggi baik di fase desain pola dan implementasi pada kain. Permasalahan lainnya adalah pemotongan bahan kain dengan ketebalan tertentu masih dilakukan dengan gunting manual karena belum mempunyai mesin potong kain listrik. Dampaknya adalah proses pemotongan bahan baku kain ukuran lebar dan tebal menjadi ukuran kecil dan siap jahit membutuhkan waktu relatif lama sehingga menghambat produksi.

Tujuan kegiatan lanjutan PKMadalahmeningkatkan kualitas pola desain dan efisiensi produksi pada UMKM jilbab dan baju muslim "Rira Clothing" di Kelurahan Rungkut Menanggal Surabaya.Secara khusus program bertujuan: (1) Meningkatkan pengetahuan, keterampilan dan kualitas desain jilbab dan baju muslim menggunakan pola desain jilbab dan baju muslim dengan motif terbaru kepada desainer, dan (2) Efisiensi waktu dan tenaga pemotongan bahan baku kain ukuran lebar dan tebal menjadi ukuran kecil dan siap jahit melalui rancang bangun inovasi teknologi tepat guna (TTG) mesin potong bahan baku kain listrik ke Mitra. Gambar 6 menunjukkan justifikasi persoalan prioritas yang disepakati untuk diselesaikan pada pelaksanaan PKM. Bagian yang dicetak tebal menunjukkan mata kegiatan untuk meningkatkan kualitas pola desain dan efisiensi produksi pada UMKM jilbab dan baju muslim "Rira Clothing"dan selanjutnya secara khusus menjadi fokus pembahasan pada makalah ini. 


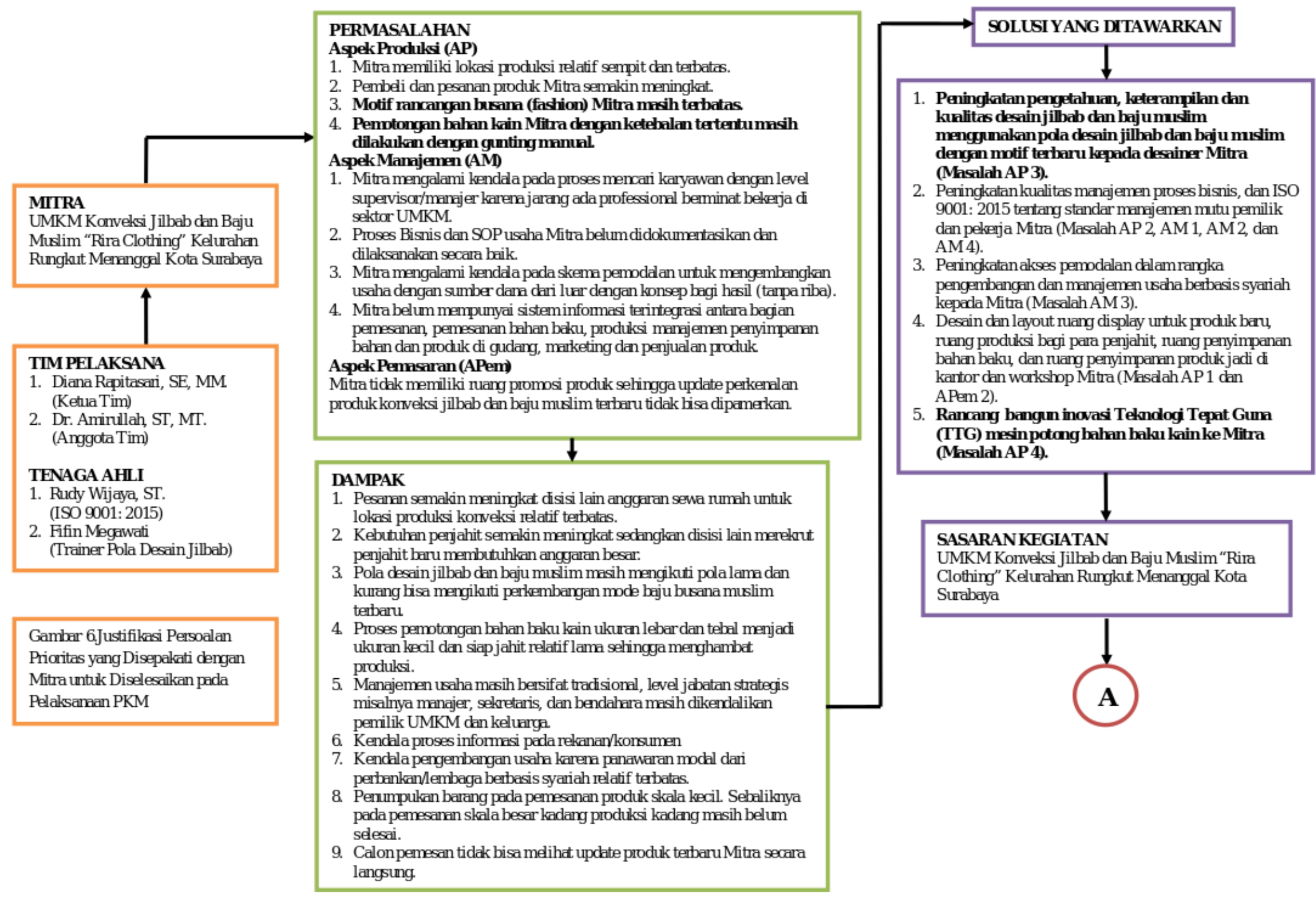

Pemotongan bahan kain dengan gunting manual

anajemen (AM)

Proses Bisnis dan SOPusaha Mitrabelumdidokumentasikand dilaksanakan secara brik.

Mitra mengalami kendala pada skema pemodalan untuk mengembangka pectic

Mitra tidak memiliki ruang promosi produk selingga update perkenala (Ketua Tim)

Dr. Amirullah ST, MT.

Trainer Pola Desain Jilbab)

Gambar 6Justifikasi Persoala

Prionitas yang Disepakati dengan

Mitra untuk Diselesaikan pad

Pelaksamaan PKM 
Gambar6. Justifikasi Persoalan Prioritas yang Disepakati dengan

Mitra untuk Diselesaikan pada Pelaksanaan PKM
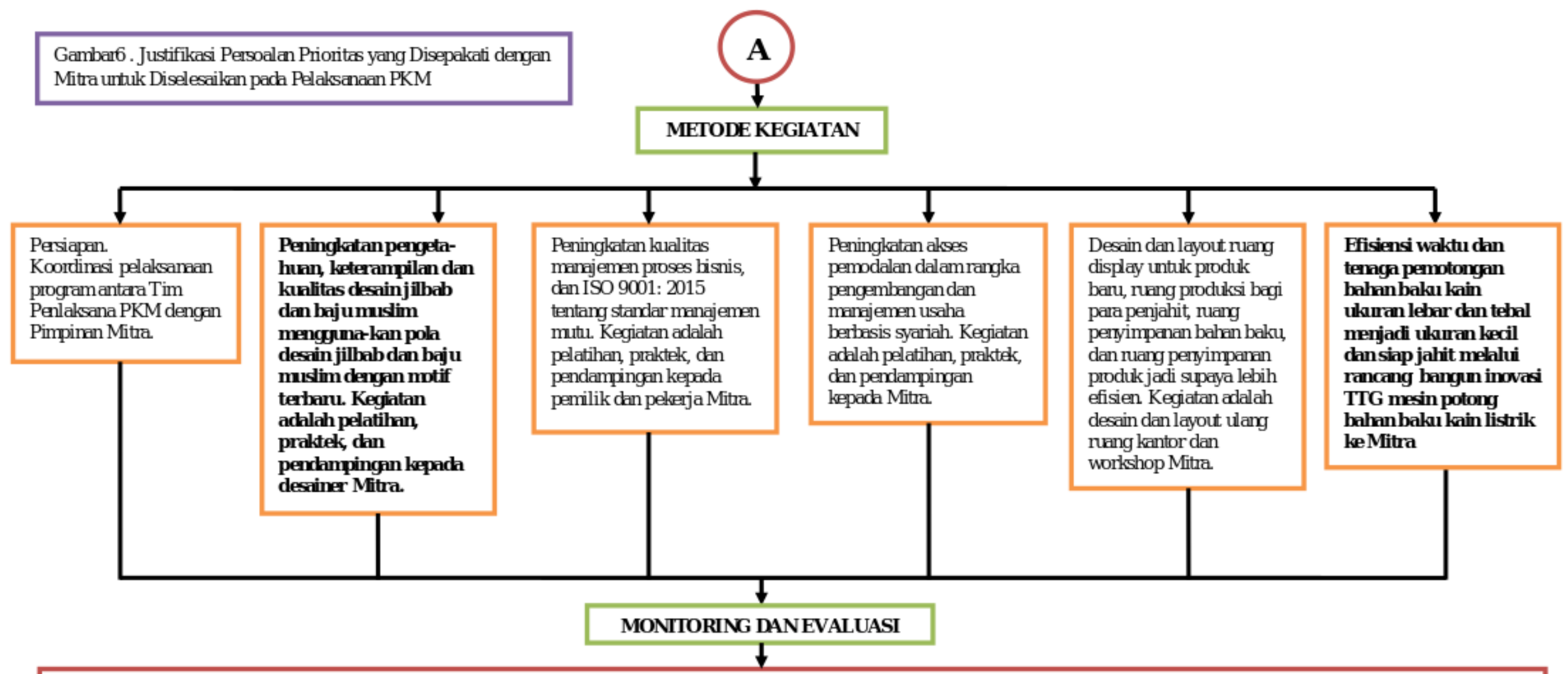

\section{TARGET LUARAN}

1. Pola desaindanproduk jilbab danbaj u muslimdengan motif terbaruhasil kreasi desainer Mitra.

2. Dokumen proses hisnis dan dan standar operasi dan prosedur(SOP) manajemen mutu usaha Mitra berbasis ISO 9001: 2015.

3. Dokumen manajemen usaha (administrasi produksi dan keuangan) Mitra berbesis syariah dan mampu mendapdt modal untuk pengembangan usaha.

4. Desain dan layout baru ruang pamer/display untuk produk baru, ruang produksi bagi para penjahit, ruang penyimpanan bahan beku, dan ruang penyimpanan produk di Mitra.

5. Inovasi baru Teknologi Tepat Guma (TTG) mesin potong bahan baku kain listrik.

6. Publikasi hasil kegiatan PKM pada artikel ilmiah di Jumal Pengabdian dan Penerapan Iptek (JPP Iptek) ITATS.

7. Publikasi hasil kegiatan PKM pada artikel ilmiah di proseding ilmiah nasional.

8. Publikasi hasil kegiatan PKM pada artike di media massa cetak/online di www.ubharaacid.

9. Dokumentasi video hasil kegiatan PKM diunggah di Youtube. 


\section{Metode Pelaksanaan}

\subsection{Metode Kegiatan}

Tujuan kegiatan lanjutan PKM adalah meningkatkan kualitas pola desain dan efisiensi produksi pada UMKM jilbab dan baju muslim "Rira Clothing" di Kelurahan Rungkut Menanggal Surabaya. Kegiatan pertama adalah pelatihan, praktek, dan pendampinganpola desain jilbab dan baju muslim dengan motif terbaru kepada desainer Mitra 2. Tujuan kegiatan adalah meningkatkan pengetahuan, keterampilan dan kualitas desain jilbab dan baju muslim menggunakan pola desain jilbab dan baju muslim dengan motif terbaru kepada desainer Mitra. Kegiatan kedua adalah rancang bangun dan inovasi TTG mesin potong bahan baku kain kepada Mitra. Tujuan kegiatan adalah efisiensi waktu dan tenaga pemotongan bahan baku kain ukuran lebar dan tebal menjadi ukuran kecil dan siap jahit melalui rancang bangun inovasi TTG mesin potong bahan baku kain listrik ke Mitra

\subsection{Partisipasi Mitra}

Dalam rangka implementasi pelaksanaan program PKM tentu dibutuhkan partisipasi mitra. Mitra memfasilitasi dan menyediakan tempat bagi pelaksanaan kegiatan pelatihan, praktek, dan pendampingan kegiatan. Mitra melakukan sosialisasi dan mobilisasi kepada anggota kedua mitra supaya mereka mengikuti semua kegiatan pelatihan, praktek, dan pendampingan PKM. Mitra memfasilitasi pembentukan panitia pelaksana terdiri dari tim pelaksana dan mitra PKM serta bertugas memberikan pengarahan dan informasi kepada anggota/pekerja Mitra tentang penyelenggaraan kegiatan PKM. Mitra memfasilitasi dan memberikan masukan kepada narasumber untuk menyukseskan kegiatan sesuai dengan target luaran setiap kegiatan PKM. Mitra membantu menyiapkan kebutuhan pendukung kegiatan pelatihan, praktik, dan pendampingan meliputi: spanduk; makalah; dan materi pelatihan, penyediaan koneksi listrik dan internet, meja-kursi, pengeras suara (sound system), dan layar LCD proyektor. Mitra mengoordinasikan kegiatan PKM kepada anggota/pekerja Mitra mengenai jadwal yang sudah ditentukan dan disepakati dengan panitia pelaksana PKM.

\section{Hasil dan Pembahasan}

\subsection{Implementasi Kegiatan PKM}

Program kegiatan PKM dilaksanakan sesuai langkah-langkah solusi atas persoalan yang disepakati antara Tim Pengusul dan Mitra. Kegiatan pertama adalah Koordinasi persiapan dengan Mitra yaitu UMKM Konveksi "Rira Clothing” (Mitra). Kegiatan kedua adalah pelatihan, praktek, dan pendampingan pola desain jilbab dan baju muslim dengan motif terbaru kepada desainer Mitra 2. Tujuan kegiatan adalah meningkatkan pengetahuan, keterampilan dan kualitas desain jilbab dan baju muslim menggunakan pola desain jilbab dan baju muslim dengan motif terbaru kepada desainer Mitra. Kegiatan ketiga adalah rancang bangun dan inovasi TTG mesin potong bahan baku kain menggunakan motor listrik kepada Mitra. Tujuan kegiatan adalah efisiensi waktu dan tenaga pemotongan bahan baku kain ukuran lebar dan tebal menjadi ukuran kecil dan siap jahit melalui rancang bangun inovasi TTG mesin potong bahan baku kain listrik kepada Mitra.

\subsection{Koordinasi Kegiatan dengan Mitra}

Untuk memastikan bahwa kegiatan PKM yang dilaksanakan berjalan sesuai dengan rencana awal, dibutuhkan koordinasi persiapan antara pelaksana dengan UMKM Konveksi "Rira Clothing” (Mitra). Kegiatan persiapan meliputi: (1) melakukan komunikasi awal tentang rencana kegiatan antara Tim Pengusul dengan Mitra PKM, (2) menentukan jadwal pelaksanaan kegiatan 
yang telah disepakati bersama antara Tim Pengusul dengan kedua Mitra PKM, (3) menentukan dan mendiskusikan jenis partisipasi mitra untuk mendukung setiap kegiatan yang diusulkan oleh pelaksana PKM. Kegiatan dilaksanakan oleh anggota pelaksana dan pimpinan mitra pada lokasi UMKM di Rungkut Barata, Surabaya hari Sabtu, 6 Juli 2019.

Kegiatan KKN PPM selanjutnya adalah pelatihan, praktek, dan pendampingan pola desain jilbab dan baju muslim dengan motif terbaru kepada desainer Mitra 2. Tujuan kegiatan adalah meningkatkan pengetahuan, keterampilan dan kualitas desain jilbab dan baju muslim menggunakan pola desain jilbab dan baju muslim dengan motif terbaru kepada desainer Mitra. Metode kegiatan adalah mengirim tiga orang tiga orang karyawan "Rira Clothing" bagian penjahit mengikuti pelatihan/kursus di Lembaga Pendidikan dan Pengajaran Tata Busana (LPTB) Susan Budihardjo di Maspion Square, Jalan Ahmad Yani, Surabaya. Narasumber dan instruktur pelatihan dari lembaga ini adalah Ibu Fifin Megawati. Pelatihan dilaksanakan selama total empat kali pertemuan masing-masing delapan jam selama bulan September 2018. Peserta pelatihan adalah karyawan penjahit dari "Rira Clothing" antara lain Imroatul Mufakhomah, Teguh Hendro, dan Sunartin. Materi pelatihan meliputi cara membuat pola dasar jilbab yaitu pola depan, pola belakang, pola lengan, pola kerah, dan pola kerudung. Pola dibuat diatas kertas putih lebar dan kain dipotong sesuai dengan pola yang telah dibuat. Potongan kain kemudian dijahit menjadi baju jilbab utuh sesuai pola dan desain yang dikehendaki desainer peserta pelatihan. Gambar 7 menunjukkan pelatihan pola desain jilbab dan baju muslim.

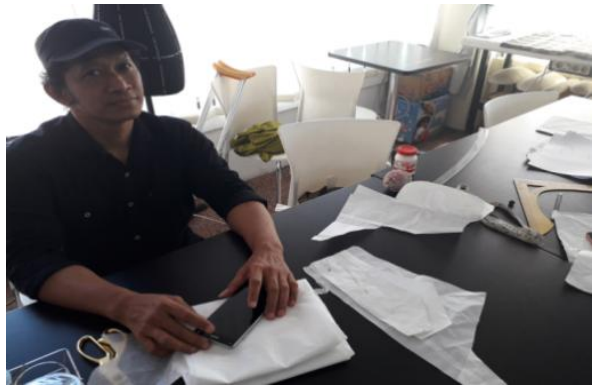

(a)

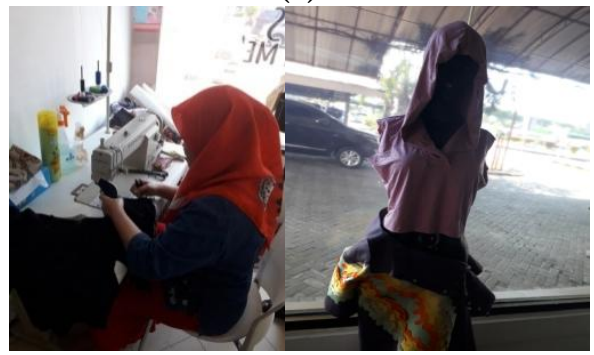

(c)

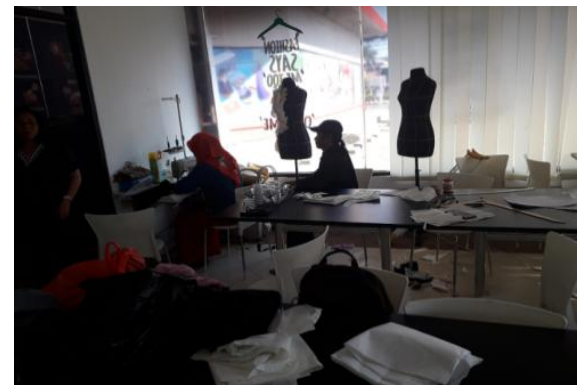

(b)

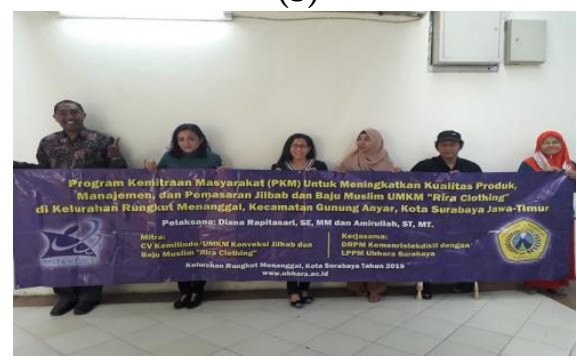

(d)

Gambar 7. (a) Pola desain jilbab dan baju muslim, (b) Menjahit kain berdasar pola yang telah dibuat, (c) Hasil pola baju jilbab di makenin, (d) Foto bersama instruktur dan peserta pelatihan

\subsection{Teknologi Tepat Guna Mesin Potong Kain}

Kegiatan selanjutnya adalah rancang bangun dan inovasi TTG mesin potong bahan baku kain kepada Mitra. Tujuan kegiatan adalah efisiensi waktu dan tenaga pemotongan bahan baku kain ukuran lebar dan tebal menjadi ukuran kecil dan siap jahit melalui rancang bangun inovasi TTG mesin potong bahan baku kain listrik ke Mitra. Spesifikasi mesin potong bahan kain tegak adalah merk KM, 10 inci, Straight Knife Cutting KM AUV, buatan Cina, dan daya 500 watt. Mesin bisa digunakan untuk memotong semua jenis kain dan sangat efisien digunakan untuk memotong hingga ketebalan 150 helai atau lapis kain dibandingkan jika menggunakan gunting 
kain manual. Kegiatan dilaksanakan lokasi Mitra di Kelurahan Rungkut Menanggal pada Jumat, 27 September 2019. Gambar 8 menunjukanTTG penggunaan mesin potong kain pada Mitra. Tabel 3 menunjukkan efisiensi penggunaan mesin potong dibandingkan menggunakan gunting kain manual.

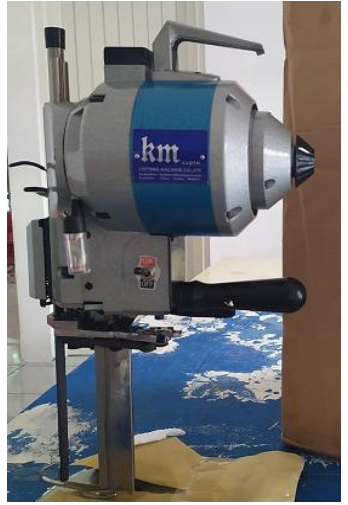

(a)

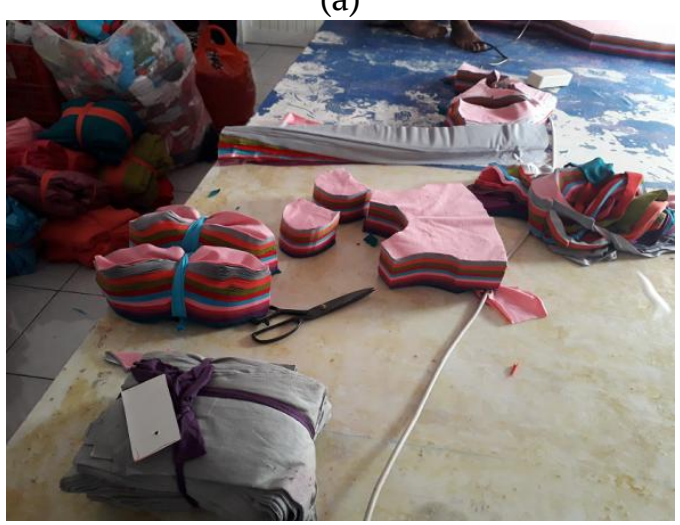

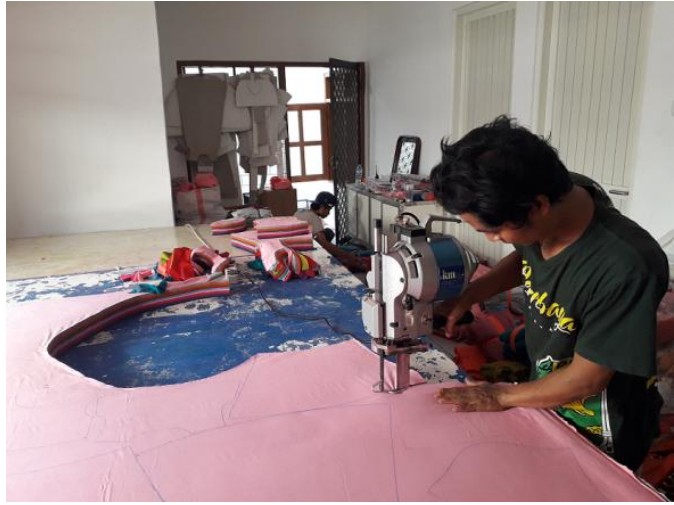

(b)

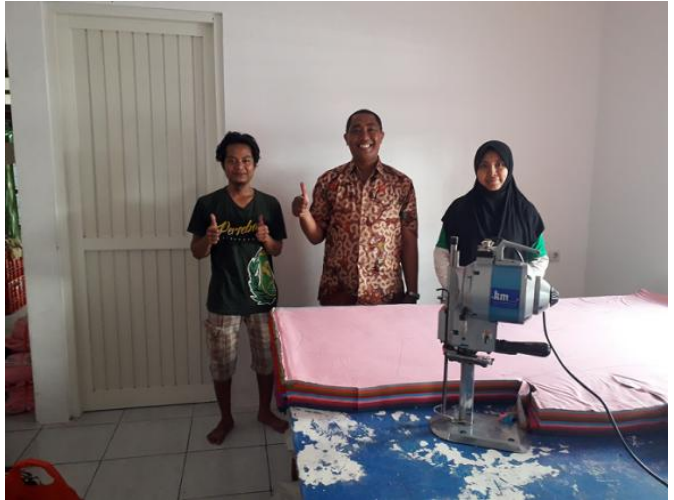

Gambar 8. (a) Mesin potong kain tebal ukuran 10 inci daya $500 \mathrm{~W}$, (b) Proses pemotongan kain, (c) Kain yang sudah dipotong, (d) Foto bersama tukang potong kain, pelaksana PKM, dan pimpinan mitra

Tabel 3. Efisiensi Penggunaan Mesin Potong Kain

\begin{tabular}{clll}
\hline No. & Parameter & Sebelum & Sesudah \\
\hline 1 & Alat & Gunting kain & Mesin potong \\
2 & Waktu & 16 jam/2 hari & 1 jam \\
3 & Tenaga & 1 karyawan & 1 orang/borongan \\
4 & Biaya Potong & Gaji bulanan & Rp200 ribu \\
5 & Ketebalan Kain & 150 helai & 150 helai \\
6 & Jenis Kain & Katun dan kaos & Katun dan kaos \\
7 & Kesalahan Potong Kain & Tinggi & Rendah \\
\hline
\end{tabular}




\section{Kesimpulan}

Program PKM melaksanakan kegiatan yang meliputi: (1) Peningkatan pengetahuan, keterampilan, dan kualitas desain jilbab dan baju muslim menggunakan pola desain jilbab dan baju muslim dengan motif terbaru kepada desainer, dan (2) Efisiensi waktu dan tenaga pemotongan bahan baku kain ukuran lebar dan tebal menjadi ukuran kecil dan siap jahit melalui rancang bangun inovasi TTG mesin potong bahan baku kain listrik ke mitra. Hasil kegiatan adalah: (1) Pola desain dan produk jilbab dan baju muslim dengan motif terbaru hasil kreasi desainer mitra dan (2) Inovasi baru teknologi tepat guna (TTG) mesin potong bahan baku kain dengan penggerak motor listrik.

\section{Ucapan Terima Kasih}

Kegiatan berjudul "Program Kemitraan Masyarakat (PKM) untuk Meningkatkan Kualitas Produk, Manajemen, dan Pemasaran UMKM Jilbab dan Baju Muslim 'Rira Clothing' di Kelurahan Rungkut Menanggal Kecamatan Gunung Anyar Kota Surabaya” dibiayai oleh Direktorat Jenderal Penguatan Riset dan Pengembangan, Kementerian Riset, Teknologi, dan Pendidikan Tinggi sesuai Kontrak Abdimas LLDikti VII dan Risbang Nomor: 111/SP2H/PPM/DRPM/2019 Tanggal 11 Maret 2019 dan Kontrak LLDikti VII dan Universitas Bhayangkara Surabaya Nomor: 007/SP2H/PPM/L7/2019 Tanggal 26 Maret 2019.

\section{Daftar Pustaka}

Dr. Ratna Panggabean, M.Sn. (n.d.). Eksplorasi Teknik Crochet Dengan Tema Warna Empat Musim Untuk Busana Muslimah. (2013), 10.

Rapitasari. (2018, September 26). Konveksi Baju Abaya. Retrieved October 18, 2019, from RiraClothing website: http://riraclothing.com/konveksi-baju-abaya/

Rapitasari, D. (n.d.). PENINGKATAN MANAJEMEN MUTU DAN PEMASARAN PRODUK UMKM JILBAB DAN BAJU MUSLIM. 2019, (2019), 12.

Sendari, A. (2019, 26T09:00:13+00:00). Cara Membuat Pola Baju Gamis, Mudah Dipraktikkan Untuk Pemula-Citizen6 Liputan6.com. Retrieved October 11, 2019, from Liputan6.com website: https://www.liputan6.com/citizen6/read/3904223/cara-membuat-pola-baju-gamis -mudah-dipraktikkan-untuk-pemula

Ulfa, R. (2016). ANALISIS SEMIOTIKA PEIRCE PAKAIAN JENIS GAMIS SEBAGAI REPRESENTASI BUDAYA ARAB. SEMIOTIKA: Jurnal Komunikasi, 10(2). https://doi.org/10.30813 /s:jk.v10i2.946 


\section{Afiliasi:}

Diana Rapitasari

Manajemen Fakultas Ekonomi dan Bisnis, Universitas Bhayangkara Surabaya

Jalan Ahmad Yani 114, Surabaya, Jawa Timur

E-mail:dianarapitasari@gmail.com

Amirullah*

Teknik Elektro Fakultas Teknik,Universitas Bhayangkara Surabaya

Jalan Ahmad Yani 114, Surabaya, Jawa Timur

E-mail: amirullah@ubhara.ac.id 